\title{
Alison Keith, Virgil, (Understanding Classics), Bloomsbury Academic, London-New York 2020, 208 pp.; ISBN 978-1-8488-5920-3
}

The aim of the Understanding Classics series from Bloomsbury Academic is to introduce the outstanding authors and thinkers of antiquity to a wide audience of modern readers. Its individual volumes do not have the character of biographies or popular companions, but focus on selected, the most characteristic aspects of the author's work, the subjects he discusses or his poetic language, presented against a broad socio-political background. These are, therefore, a kind of introduction for advanced users, such as graduate students of the classics, literature, philosophy or ancient history, aimed at encouraging them to deepen their reading of well-known authors.

This is also the nature of a new volume in the series, dedicated to Virgil, by Alisson Keith, Professor of Classics at the University of Toronto, Canada, who specialises in Roman poetry of the Augustan Age. Her earlier books include The Play of Fictions: Studies in Ovid's Metamorphoses Book 2 (The University of Michigan Press 1992), Engendering Rome: Women in Latin Epic (Cambridge University Press 2000) and Propertius, Poet of Love and Leisure (Bristol Classical Press 2008).

The book is divided into five chapters devoted respectively to Virgil's life and the historical context of his oeuvre ("Life and Times," pp. 1-15), three of the poet's works (“Bucolica," pp. 17-49; “Georgica," pp. 51-88; “Aeneis," pp. 89-132) and their later reception ("Reception," pp. 133-150). All of the chapters were written in a professional and accessible manner and are - considering the specificity and audience of the seriesrather exhaustive and a good introduction to reading Virgil and to the latest state of research.

Within the chapters devoted to the poet's works, we can distinguish some recurring modules concerning literary and philosophical traditions to which he referred, as well as - in the case of the Bucolica and the Aeneis - subchapters on the historical and political significance of these works. It is also notable that Keith paid special attention to those aspects of Virgil's works which have started to attract more attention only recently, such as Epicureanism in the Bucolica and the Georgica. Many topics, such as Aeneas' development as a hero, were only mentioned in passing and others were omitted altogether, but in a work with a deliberately imposed limited form this cannot be regarded as a serious drawback, as all the most important things have been included.

However, it is a reviewer's duty to also point out two small but significant shortcomings of the work. In the introductory chapter and further in the book, a certain omission catches our attention, which is probably the result of the popular practice of shortening ancient authors' names. Namely, the author states already on page one 
that Donatus' commentary on all of Virgil's works was lost, which is true. What she does not mention, however, is that apart from Aelius Donatus, who is at present known mainly for his very influential grammar textbook, Ars maior and Ars minor, as well as a short biography of Virgil — which, incidentally, Keith cites many times - another grammarian who studied Virgil's works lived in his times and, what is more, had the same cognomen-Tiberius Claudius Donatus. His monumental commentary on the Aeneis, mainly focusing on the style and rhetoric, the so-called Interpretationes Vergilianae, has survived to our times in its entirety (ed. H. Georgii, Leipzig 19051906/1912; Stuttgart 1969). Until quite recently, both authors were mistaken for each other even in serious monographs, ${ }^{1}$ so when writing about Donatus it is worth specifying which of the two namesakes one means. Moreover, Claudius Donatus deserves at least a mention in a work devoted to Virgil.

The other criticism concerns the chapter on the reception of Virgil's works, in which the author omitted a poem by Flavius Cresconius Corippus, an African epic poet from the 6th c., who in his poem Iohannis seu de bellis Lybicis libri VIII alluded to the Aeneis in a much more direct way than Lucan, Statius or Silius Italicus, as he based the image of his main character, the Byzantine general John Troglita, on the figure of Aeneas. Another quite important work omitted by the Author is the antiquarian-historical treatise Origo gentis Romanae (dated variously), which was included in the 4th-century compilation known as the Corpus Aurelianum. Its author, describing Rome's earliest history, compared the historical material to the Aeneis, which is an unusual and very interesting example of the brilliant epic poet's work being adapted by Roman erudite prose (of course, many more such examples of Virgil's reception could be listed). As for later reception, the reader may feel somewhat surprised by the fact that up until the early modern period Keith discusses the reception of Virgil's oeuvre in a comprehensive way, and later basically limits herself to literature written in English, as if all other European literature ended with the work of Francesco Petrarca. Apart from this astonishing limitation, which is again likely a result of limited space and the author's literary predilections, it should be said that also this chapter works well as an introduction to the topic of Virgil's reception (especially for native speakers of English). To sum up, the reviewed book should be regarded as very good and worth recommending both to students and other readers, who are only just starting their adventure with Virgil.

Bartosz Jan Kołoczek

http:/orcid.org/0000-0003-1401-0093

Jagiellonian University in Kraków

1 On this topic see e.g. G. B. Conte, Letteratura latina, vol. II: L'età imperiale, Firenze 2012, 259260. A meagre, just a few items long, bibliography of literature on the subject of this author is given by J. E. G. Zetzel in Critics, Compilers and Commentators: An Introduction to Roman Philology, 200 BCE800 CE, Oxford University Press 2018, 266. 